\title{
A LONG WAY FROM HOME
}

\author{
Distant memories.
}

\section{BY SYLVIA SPRUCK WRIGLEY}

$\longrightarrow$ reat-Aunt Gertrude chopped up the dried fruit while I stirred the batter. The fridge updated: we were 982,000 kilometres from Earth exactly. "Look, Mom, look," Lorissa shouted. She was waiting for all nines.

"Very exciting, pumpkin." I tried to look enthused.

Great-Aunt Gertrude was lecturing, as usual. "If you want to do it right, you must to mix it by hand, not using the electric mixers."

Lorissa crawled up on the stool, took the wooden spoon from me. "You are best helper," Great-Aunt Gertrude told her. "Much better than your mother. She's not careful when she stirs." Lorissa nodded, her chubby face serious as she carved careful paths into the batter. I held my tongue.

We didn't keep track of the Earth calendar on the ship. But Great-Aunt Gertrude had decided that this was a good time to celebrate Weihnachten. Never mind that no one had any presents or that there wasn't any point to wishing for peace on Earth and mercy mild. Lorissa decorated the lounge with cotton-ball snow and we sang all the carols and ate the lebkuchen. You didn't say no to GreatAunt Gertrude.

Hugh sat in the comms room, as always. "Merry Christmas from Sittner735, is anybody out there?"

When Great-Uncle Herbert told us that he'd bought a fully laden escape shuttle, we all said he was crazy. He'd wasted his entire pension, fallen for scammers, gone senile. When the war started, he must have been pretty tempted to leave us all behind for laughing at him. But that would have left him alone for all eternity with Great-Aunt Gertrude, so he forgave us and made sure we all got on board. Thing is, no one knew how to drive the navigation system. Hugh, my husband, kept trying the radio in the hope of making contact with some other evacuees, but again, no one really knew what frequencies we should use or anything. So, there it

$\rightarrow$ NATURE.COM

Follow Futures:

@ @NatureFutures

f go.nature.com/mtoodm was, six of us heading out into space, waiting to see how far this ship could go.

Every 28 cycles,
Great-Aunt Gertrude declared it was Weihnachten and the whole damn thing would start over. I knew it was every 28 cycles because she was right in sync with my period, so just as my back cramps kicked in, it was "come to the kitchen and help your baby stir the batter" like we hadn't just done this already.

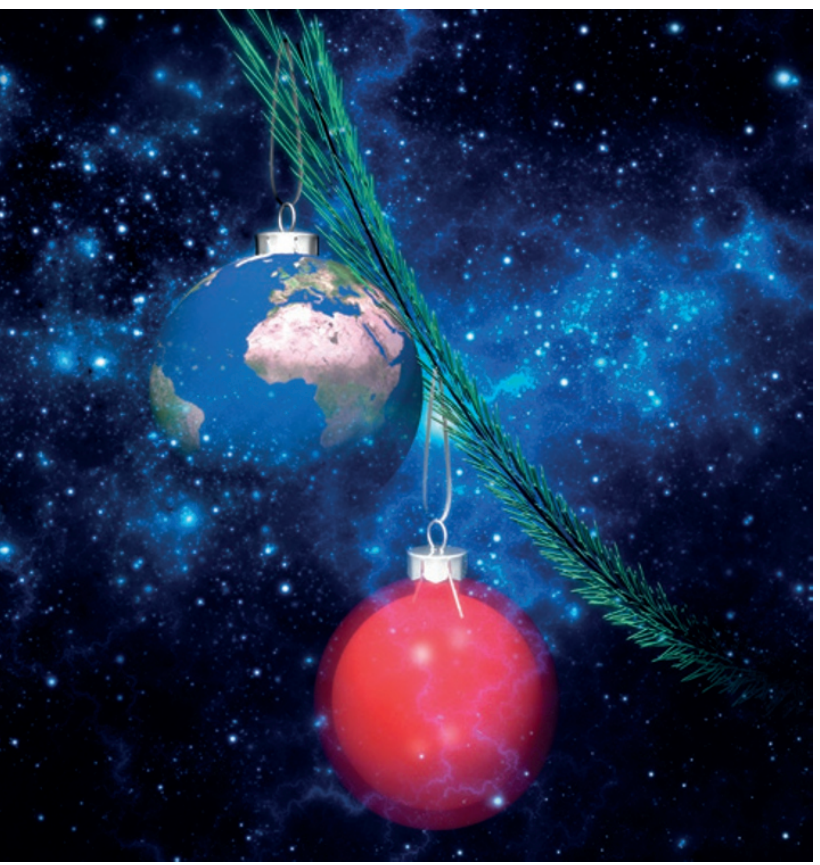

This was the fourth Christmas celebration. Lorissa had just showed me the fridge display ticking over to 989,500 kilometres from Earth when Great-Aunt Gertrude collapsed. I carried her to her quarters, struck by how light she'd become in the few months since we left home. Great-Uncle Herbert ignored her, as always, sitting in the library studying his digital collection of star-system maps. Hugh called out into space, searching for signs of life. I sat with her every day. She had become small and frail overnight, her skin taut across her bones. I patted her hand and Lorissa brought her mugs of tea which she never drank. Sitting there day after day, I felt useless and angry and cold.

"Lorissa, go play with your father," I snapped after she asked me for the fifteenth time whether there was any lebkuchen left.

"He told me to come here," she whined. That was the final straw. I stormed to the radio room where Hugh sat, clutching the microphone as if it could save him. "Can't you just put that down for ten minutes and take care of your daughter? Do I have to do everything?"

He turned and gave me a slow, hard glare. I stood my ground. "I'm trying to look after my aunt and Lorissa is constantly underfoot and all you do is sit there mumbling into the black like suddenly the Johnsons are going to turn up right next door. Don't you know it's hopeless?"

I wanted him to shout or rage or do something but he just stared at me and finally said in a low voice: "What do you want me to do?"

His cold face scared me more than anything else so far. "Help me with Great-Aunt Gertrude."

He shook his head. "How? She's out of pills, out of time."

"What?" My heart pounded as I realized the truth of it. "Who would be so stupid? Surely they must have bought spares, stocked up with a lifetime's supply when they bought the crates of spam and powdered ginger."

"Yeah, the doctor would totally write out the prescription for that," he said. He laughed. I stared at him, uncomfortably aware that I'd barely spoken to him in months. He was in here, day and night, calling out on the radio. "What's she going to do with all those pills, anyway?" He put down the mike and stepped close to me but didn't reach out. "Where do you think we are going, exactly?"

"Well, the ship's programmed, right? So we'll head out into space and then back again once the fall-out has cleared."

Hugh stared at me in that same way, as if he were looking at a stranger. Then he just shook his head and sat back down. "Sittner735, does anyone read?"

Lorissa ran into the comms room. "Is it Weihnachten again soon?" I took her to the kitchen and got the bowl down. "We'll make lebkuchen for Great-Aunt Gertrude," I told her. "Every day, for as long as we can."

The fridge ticked over: 997,799 kilometres. And only now had I realized that there was nowhere for our family to go.

Sylvia Spruck Wrigley was born in Germany and spent her childhood in Los Angeles. She now splits her time between South Wales and the Costa del Sol, two coastal regions with almost nothing in common. You can find out more about her at www.intrigue.co.uk. 